\title{
An analysis of China's climate policy using the China-in-Global Energy Model
}

Tianyu $\mathrm{Qi}^{\AA^{\dagger^{*}}}$, Niven Winchester ${ }^{\S}$, Valerie J. Karplus ${ }^{\S}$, Da Zhang ${ }^{\S \dagger}$, and Xiliang Zhang $^{\dagger}$

\begin{abstract}
The primary approach to address climate change in China has been the use of $\mathrm{CO}_{2}$ intensity targets coupled with targets for low carbon energy deployment. We evaluate the impact of extending similar targets through 2050 on China's energy use profile and $\mathrm{CO}_{2}$ emissions trajectory using the China-in-Global Energy Model (C-GEM). The CGEM is a global computable equilibrium model that includes energy and economic data provided by China's statistical agencies, calibration of savings, labor productivity, and capital productivity dynamics specific to China's stage of development, and regional aggregation that resolves China's major trading partners. We analyze the combined impact of extending $\mathrm{CO}_{2}$ intensity targets, implemented via a cap-and-trade program, and low carbon energy policies (directives for nuclear power expansion and feed-in tariffs for wind, solar, and biomass energy) through 2050. Although with the policy, simulated $\mathrm{CO}_{2}$ emissions are around $43 \%$ lower in 2050 relative to a reference (No Policy) counterfactual, China's $\mathrm{CO}_{2}$ emissions still increase by over $60 \%$ between 2010 and 2050. Curbing the rise in China's $\mathrm{CO}_{2}$ emissions will require fully implementing a $\mathrm{CO}_{2}$ price, which will need to rise to levels higher than $\$ 25 /$ ton in order to achieve China's stated goal of peaking $\mathrm{CO}_{2}$ emissions by 2030 .
\end{abstract}

Keywords: $\mathrm{CO}_{2}$ intensity; climate policy; China; low carbon energy

JEL codes: O5; Q4; Q54;

\footnotetext{
* Corresponding author: Tianyu Qi, E-mail: apollo110110@gmail.com. Institute of Energy, Environment and Economy, Tsinghua University, Beijing, China.

$\S$ Joint Program on the Science and Policy of Global Change, Massachusetts Institute of Technology, 77 Massachusetts Avenue, Room E19-411, Cambridge, MA, USA.

$\dagger$ Institute of Energy, Environment and Economy, Tsinghua University, Beijing, China.
} 


\section{Acknowledgments}

The authors thank Eni S.p.A., ICF International, Shell International Limited, and the French Development Agency (AFD), founding sponsors of the China Energy and Climate Project. We are also thankful for support provided by the Ministry of Science and Technology of China, the National Development and Reform Commission, and Rio Tinto China. We further gratefully acknowledge the financial support for this work provided by the MIT Joint Program on the Science and Policy of Global Change through a consortium of industrial sponsors and Federal grants, including the U.S. Department of Energy. This work is also supported by the DOE Integrated Assessment Grant (DE-FG02-94ER61937). We also gratefully acknowledge the editorial assistance of Marshall Spriggs in preparing an earlier version of this manuscript. 


\section{Introduction}

China has emerged as the world's largest energy consumer and source of greenhouse gas (GHG) emissions (Nicola, 2007; IEA, 2013). Given the scale of China's economy and energy system, its energy trends and climate policies will have a significant impact on global climate change mitigation. Since the start of China's Eleventh Five-Year Plan (2006-2010) policymakers have increasingly emphasized control of the country's rising energy use and carbon dioxide $\left(\mathrm{CO}_{2}\right)$ emissions. Targets for energy intensity, non-fossil energy, and $\mathrm{CO}_{2}$ emissions intensity formed the core of China's climate policy during the present Twelfth Five-Year Plan (2011-2015). Recognizing the importance of incentives to support these targets, seven pilot emissions trading systems that price $\mathrm{CO}_{2}$ are currently being established in provinces and cities across China from 2013 and 2015 (Zhang et al., 2014).

The China-in-Global Energy Model (C-GEM) is a new tool to analyze climate and energy polices in China. The model was developed by the China Energy and Climate Project (CECP), a cooperative effort of Institute of Energy, Environment, and Economy at Tsinghua University, and the Joint Program on the Science and Policy of Global Change at the Massachusetts Institute of Technology (MIT). The primary goal of the model is to simulate existing and proposed energy and climate polices in China in order to analyze their impact on technology choices, inter-fuel competition, the environment, and the economy within a global context.

The C-GEM is a recursive dynamic global computable general equilibrium (CGE) that links $\mathrm{CO}_{2}$ emissions to economic activity. The C-GEM builds on other energyeconomic models, such as the MIT Emissions Prediction and Policy Analysis (EPPA) model (Paltsev et al., 2005) by providing a platform tailored to evalaute outcomes in China. This is achived by selecting sectoral and region aggregations most appropriate for China, merging China's official data with a global dataset, and using China-specific estimates of the costs of advanaced electricity generation technologies. 
In the C-GEM, policy acts primarily through changes in the relative prices of goods as economic activities adjust to reflect a new equilibrium that meets all policy constraints at least cost. Energy policies that can be represented in a CGE framework range from market-based instruments such as a carbon charge or tax on fuels to command-and-control policies that directly constrain the quantity or efficiency of energy use, or require the application of specific energy technologies. Examples of policy modeling efforts employing CGE models with structural similarities to CGEM - used independently or in connection with natural systems models in integrated assessment studies_-are numerous (Böhringer and Löschel, 2006; Babiker et al., 2004; Babiker et al., 2003; Boehringer et al., 2012; Melillo et al., 2009).

Several other studies have developed CGE model to assess climate and/or energy policies. We review these studies below and summarize model features in Appendix Table 1. As is evident from the large number of studies included in this table, CGE models have been developed and employed to examine a wide range of issues, such as distributional impacts of climate policy under alternative allowance allocation schemes (Rausch et al., 2010), dynamics of energy system transition (Böhringer and Rutherford, 2013), and the impact of policy on interactions between fuels markets and labor markets (Al Shehabi, 2013). Models vary in the extent of regional disaggregation, representing single countries or regions, or capturing regional or sub-regional detail within models of the global economy. Only the Rausch et al. (2010), Brink et al. (2014) and Capros et al. (2013) models include a Hotelling specification for resource exhaustion, while over half the models have some treatment of backstop technologies. ${ }^{1}$

We contribute to this literature by developing and exercising a new recursivedynamic projection model with global coverage and special attention to the

\footnotetext{
${ }^{1}$ For other CGE studies we refer the reader to Kitwiwattanachai et al. (2010), Bor and Huang (2010), AsafuAdjaye and Wianwiwat (2012), Jorgenson and Yun (2012), Adams and Parmenter (2013), McKibbin and Wilcoxen (2013), Capros et al. (2013), Bao et al. (2013), and Fujimori et al. (2014). Details of the CGE models employed in these analyses are included in Appendix Table 1.
} 
representation of China. In addition to Hotelling resource depletion, region-specific representation of advanced technologies, and detailed in-country data for China, distinguishing features of our model include the representation of structural changes expected in the Chinese economy (to our knowledge, not incorporated in any of the other models) as well as the calibration to 2010 observed data for China, which is important given the rapid growth and sectoral shifts experienced in that country during the first decade of the 2000s. Specifically, the C-GEM was constructed using the eighth (latest available by the paper submission date) release of the Global Trade Analysis Project data set (GTAP8) (Narayanan et al., 2012), and data for the China are replaced with China's officially-released national input-output tables (National Bureau of Statistics of China, 2009). The dynamic calibration from 2007 to 2010 was adjusted to observations as closely as possible. The C-GEM model has been applied in previous peer-reviewed studies, including Qi et al. (2014a) and Qi et al. (2014c).

In the following four sections, we provide a description of the C-GEM and utilize this framework to evaluate the impact of core mechanisms enacted in China to reduce $\mathrm{CO}_{2}$ emissions. Section 2 describes the framework, key assumptions and data sources underpinning the C-GEM. Section 3 presents scenarios simulated using the C-GEM. Section 4 presents the results, and Section 5 offers concluding remarks.

\section{Modeling Framework}

Our analysis involves developing and employing the C-GEM, a computable general equilibrium (CGE) model, to evaluate energy and climate policies in China in a global setting. The C-GEM is a global recursive-dynamic, multi-regional CGE model that captures both economic activity and associated energy flows. C-GEM takes 2007 as the base year, and the first period last from 2007 to 2010. After 2010, C-GEM takes five 
years as one period and continues to 2050. Key features of the model are discussed below. We provide a detailed description of the C-GEM in Qi et al. (2014b) ${ }^{2}$.

\subsection{Model regions and sectors}

The C-GEM distinguishes 19 geographic regions, as shown in Table 1. An important feature of the regional aggregation is the representation of China and major economies surrounding this country (Japan, South Korea, Developed Asia, Developing South-East Asia, and Rest of Asia). Elsewhere, the model identifies major developed and developing economics (e.g., the US, the EU, India, Russia and Brazil) as separate regions, while other economies are included in composite regions (e.g., Australia-New Zealand, the Middle East, Africa and Latin America).

Table 1. Regions in the C-GEM.

\begin{tabular}{|c|c|}
\hline Regions in the C-GEM & Major economies in each region \\
\hline \multicolumn{2}{|l|}{ Developed Economies } \\
\hline United States (USA) & United States \\
\hline Canada (CAN) & Canada \\
\hline Japan (JPN) & Japan \\
\hline South Korea (KOR) & South Korea \\
\hline Developed Asia (DEA) & Hong Kong, Taiwan, Singapore \\
\hline Europe Union (EUR) & EU-27 plus countries in the European Free Trade Area \\
\hline Australia-New Zealand (ANZ) & Australia, New Zealand and other South Pacific territories \\
\hline \multicolumn{2}{|l|}{ Developing Economies } \\
\hline China $(\mathrm{CHN})$ & Mainland China \\
\hline Developing South-East Asia (SEA) & Indonesia, Malaysia, Philippines, Thailand, Vietnam, Cambodia, Laos \\
\hline Rest of Asia (ROA) & Bangladesh, Sri Lanka, Pakistan, Mongolia \\
\hline Mexico (MEX) & Mexico \\
\hline India (IND) & India \\
\hline Middle East (MES) & Iran, Bahrain, Israel, Kuwait, Oman, Qatar, Saudi Arabia \\
\hline South Africa (ZAF) & South Africa \\
\hline Rest of Africa (AFR) & African countries not elsewhere classified \\
\hline Russia (RUS) & Russia \\
\hline Rest of Eurasia (ROE) & Croatia, Belarus, Ukraine, Armenia, Azerbaijan, Georgia, Turkey, Kazakhstan \\
\hline Brazil (BRA) & Brazil \\
\hline
\end{tabular}

2 This paper builds on the description of the C-GEM in Qi et al. (2014b). 
Production within each region is comprised of 20 industrial sectors, shown in Table 2. Important industries for analysis of climate and energy policies include energy sectors (coal, oil, natural gas, refined oil and electricity) and energy-intensive industries (non-metallic mineral products; iron and steel; non-ferrous metals products; chemical, rubber and plastic products; and fabricated metal products). Other sectors represented in the model include three agricultural sectors, two service sectors, and five other production sectors that capture manufacturing activities not classified as energy intensive and non-fossil fuel mining.

Table 2. Descriptions of the 20 industry sectors in the C-GEM.

\subsection{Data}

As a multi-regional CGE model, the C-GEM is based on a balanced social accounting matrix (SAM) for each region. A SAM is built on an input-output table and represents the flows of economic transactions between households and production sectors, and among production sectors through the use of intermediate inputs. The model also includes data that tracks (i) bilateral trade data among regions, (ii) the physical quantity of carbon-based fuels produced or used by each sector, and (iii) $\mathrm{CO}_{2}$ emissions from the combustion of fossil fuels (non- $\mathrm{CO}_{2}$ greenhouse gases are not currently represented).

We source global bilateral trade data and, for all regions except China, SAM data from Version 8 of the Global Trade Analysis Project (GTAP) database (Narayanan et al., 2012). This database provides a representation of the global economy in 2007. Energy physical data for all regions outside China is also sourced from the GTAP database and draws on the International Energy Agency's (IEA's) Extended Energy 


\begin{tabular}{|c|c|c|}
\hline Type & Sector & Description \\
\hline \multirow{3}{*}{ Agriculture } & Crops (CROP) & Food and non-food crops \\
\hline & Forest (FORS) & Managed forest land and logging activities \\
\hline & Livestock (LIVE) & Animal husbandry and animal products \\
\hline \multirow{5}{*}{ Energy Sectors } & Coal (COAL) & Mining of hard coal, lignite and peat \\
\hline & Oil (OIL) & Extraction of crude oil \\
\hline & Gas (GAS) & Extraction of natural gas \\
\hline & Petroleum (ROIL) & Refined oil and petro-chemical products \\
\hline & Electricity (ELEC) & Electricity generation, transmission and distribution \\
\hline \multirow{5}{*}{ Energy-Intensive } & Non-Metallic Minerals Products (NMM) & Cement, plaster, lime, gravel and concrete \\
\hline & Iron \& Steel (I\&S) & Manufacture and casting of iron and steel \\
\hline & Non-Ferrous Metals Products (NFM) & Production of copper, aluminum, zinc, lead, etc \\
\hline & Chemicals, Rubbers and Plastics (CRP) & Chemical, rubber plastic products \\
\hline & Fabricated Metal Products (FMP) & Metal products (except machinery and equipment) \\
\hline \multirow{5}{*}{ Other Production } & Food \& Tobacco (FOOD) & Manufacture of food products and tobacco \\
\hline & Mining (MINE) & Mining of metal ores, uranium, gems and quarrying \\
\hline & Construction (CNS) & Construction of houses, factories, offices and roads \\
\hline & Equipment (EQUT) & Machinery and equipment, including electronics \\
\hline & Other Industries (OTHR) & Industries not classified elsewhere \\
\hline \multirow{2}{*}{ Services } & Transportation Services (TRAN) & Pipeline transport, and water, air and land transport \\
\hline & Other Services (SERV) & Communication, finance, public services, dwellings \\
\hline
\end{tabular}

Balances dataset (IEA, 2007). Version 8 of the GTAP database represents 129 regions and 52 industry sectors, which we map to the 19 regions and 20 sectors listed in Table 1 and Table 2.

To parameterize production in China, we use this nation's 2007 national inputoutput table produced by the the National Bureau of Statistics of China or NBS (2009). This input-output table represents the structure of production for 135 industry sectors. There is an exact mapping of these 135 sectors to the 20 sectors represented in the CGEM, except for the oil and natural gas sectors, which are grouped in the same sector in China's national statistics. As the individual representation of oil and natural gas is important for energy policy assessment, we separate this production into two sectors according to their value shares in the GTAP database. Differences in the entries for China in the GTAP and NBS national data sets are small. We use the NBS national data 
because it includes adjustments made to the 2007 data during the 2010 economic census, which were not included in earlier data used in the development of the GTAP data set. After mapping the NBS data to match the GTAP sector structure and verifying that no large deviations exist, the merger of the two datasets is straightforward.

Energy volume production and use data is sourced from China's 2007 Energy Balance Table and China's Industry Energy Consumption Table (National Bureau of Statistics of China, 2008). These tables provide information on intermediate and final energy consumption for 39 industrial sectors as well as for households in 2007. The energy data is readily mapped to the sectors in the C-GEM except transportation, which is grouped with "Storage, postal, and telecommunications services" in China's official data. To disaggregate these data, we split total energy for this sector in accordance with energy volume shares in the GTAP database. To keep energy values and volume data consistent with China's official statistics, we calibrate them using energy price information from the 2008 Price Year Book of China (China Price Year Book Press, 2009). After merging the GTAP and China's national data, we rebalance the global database using the least-squares approach described by Rutherford (2010).

\subsection{The static model}

The core static model in the C-GEM captures a snapshot of relationships among producers, consumers, government, and interactions among regions through trade. These relationships are updated in each time period, as described in Section 2.4. Equilibrium in each period in the C-GEM is set up and solved as a mixed complementarity problem, in which the equilibrium conditions are comprised of a system of weak inequalities and complementary slackness conditions (between equilibrium variables and equilibrium conditions).

The structure of the core static model in the C-GEM is derived from the Walrasian general equilibrium theory formalized by Arrow and Debreu (1954). The model involves producers that maximize profits subject to prices and available technologies, 
consumers that own the factors of production and maximize welfare subject to budget contraints, and governments that collect taxes and spend revenue on consumption and transfers to households. Under this framework, three conditions define a perfectly competitive equilibrium: (i) output prices equal the cost of all inputs so that profits are zero; (ii) supply equals demand for each commodity and factor so that markets clear, and (iii) the income of each agent is equal to her expenditure (income balance). ${ }^{3}$ Detailed formulations of these conditions can be found in Rutherford (2010).

\section{Production and consumption}

Production in each sector is represented by series of nested constant elasticity of substitution (CES) functions in the C-GEM, where nesting structures, input cost shares and elasticity values differ across sectors (or groups of sectors) to reflect the characteristics of each industry. The nesting structure for primary fossil fuels (coal, crude oil and gas) and mining is shown in Figure 1, and the production structure for all other sectors except agricultural sectors, refined oil and electricity is illustrated in Figure 2. In production diagrams, $\sigma$ is used to denote the elasticity of substitution among inputs in a given nest. For primary fossil fuels and mining, natural resources combine with non-resource inputs, which allows production of each sector to be calibrated to a desired supply elasticity following Rutherford (2002a).

\footnotetext{
${ }^{3}$ In some circumstances the zero profit and market clearance conditions will not hold. Specifically, as the model is specified as a mixed complementarity problem, if unit costs are greater than the price, the commodity in question will not be produced, and if supply is greater than demand, the price of the associated good or factor will be zero.
} 


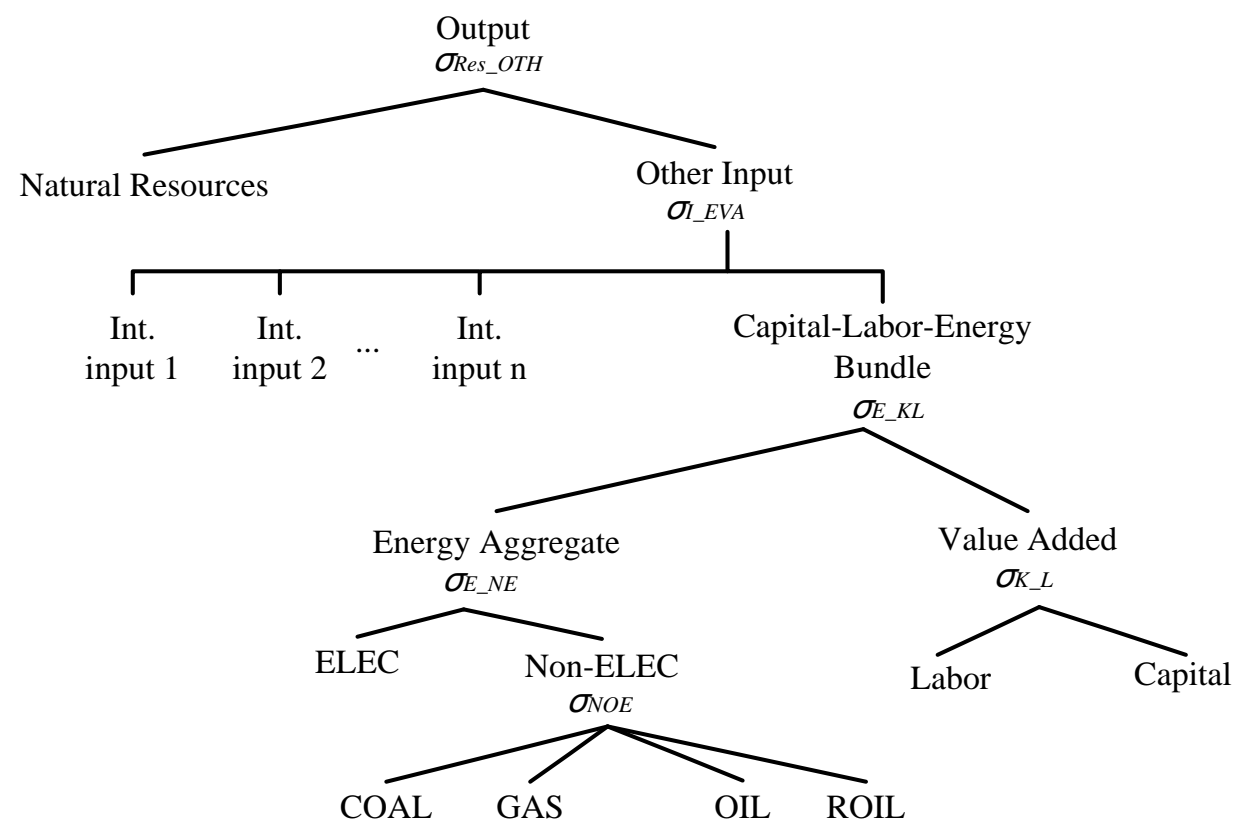

Figure 1. The structure of primary fossil energy sectors (coal, oil and gas) and mining in the C-GEM.

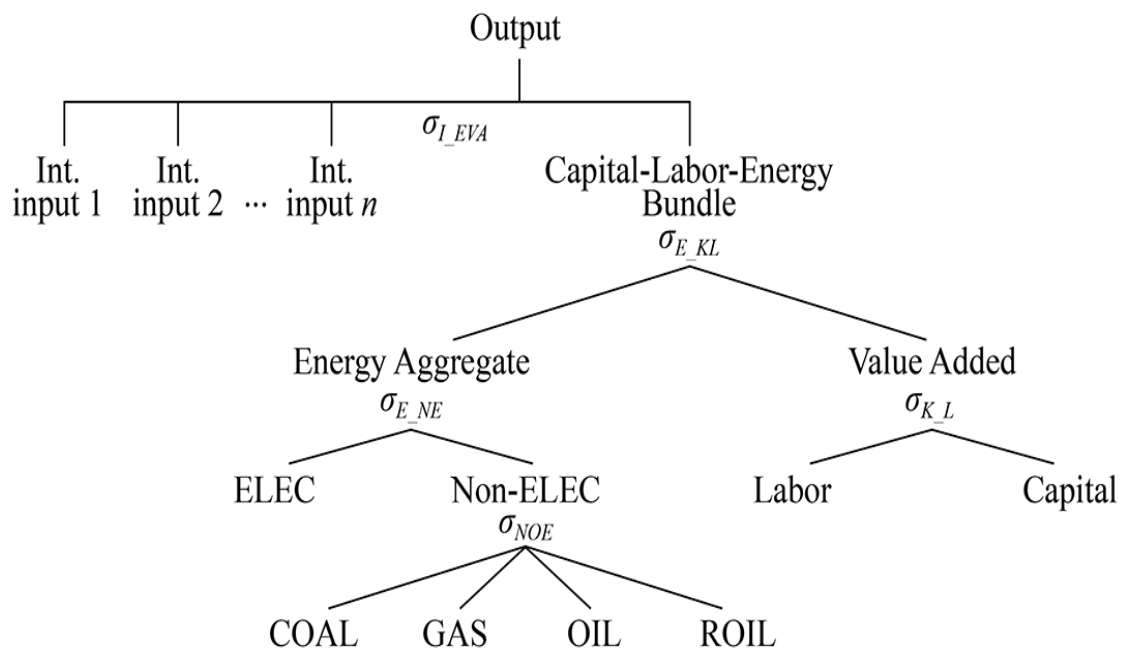

Figure 2. The structure of energy-intensive, services and other production (except mining) sectors in the C-GEM.

Important features illustrated in the figures and common to all production functions include substitution possibilities among energy inputs, as captured by the Non-ELEC and Energy Aggregate nests, and between the Energy Aggregate and Value Added (capital and labor). These features allow producers to respond to policies such as a 
carbon price by substituting towards less-carbon intensive fuels and using energy more efficiently by spending more on capital and labor.

Also common to most production functions, the Capital-Labor-Energy bundle enters in a Leontief nest with non-energy inputs, as shown in Figure 1 and Figure 2. The production structure for refined oil is similar to that depicted in Figure 2, with the exception that crude oil enters in a Leontief nest with other intermediate inputs rather than in the Energy Aggregate.

The production structure for agricultural sectors includes land inputs and is shown in Figure 3. This structure allows producers to tradeoff land for energy and intermediate inputs and the land-intermediates bundle for capital and labor. These substitution possibilities among land and other inputs follow approaches used by Paltsev et al. (2005) and allow yields to increase in response to rising land prices by using greater quantities of inputs such as machinery and fertilizer.

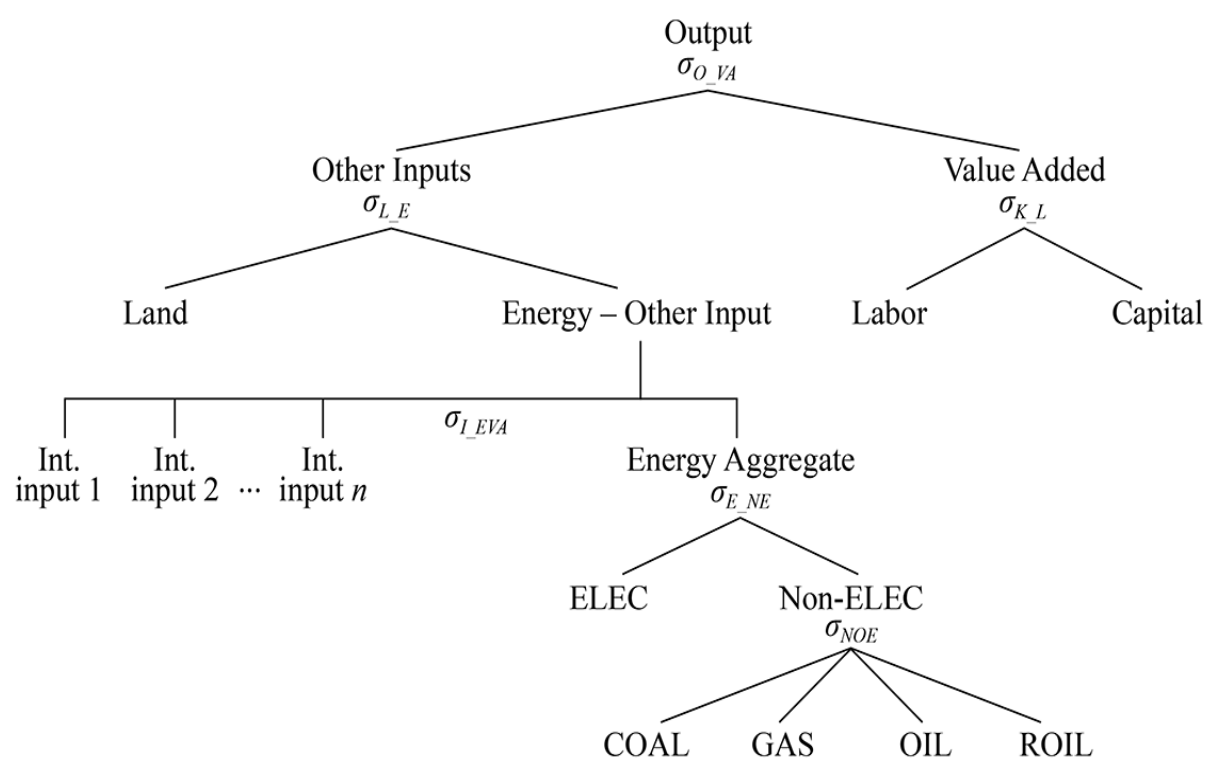

Figure 3. The structure of agricultural sectors in the C-GEM.

The structure of the electricity sector is shown in Figure 4. The top two nests permit substitution among 13 generation technologies represented in the C-GEM. As listed in Table 3, these technologies are a mix of conventional technologies, which operate at 
large scale in the base year, and advanced technologies, which do not exist or do not operate at large scale in the base year.

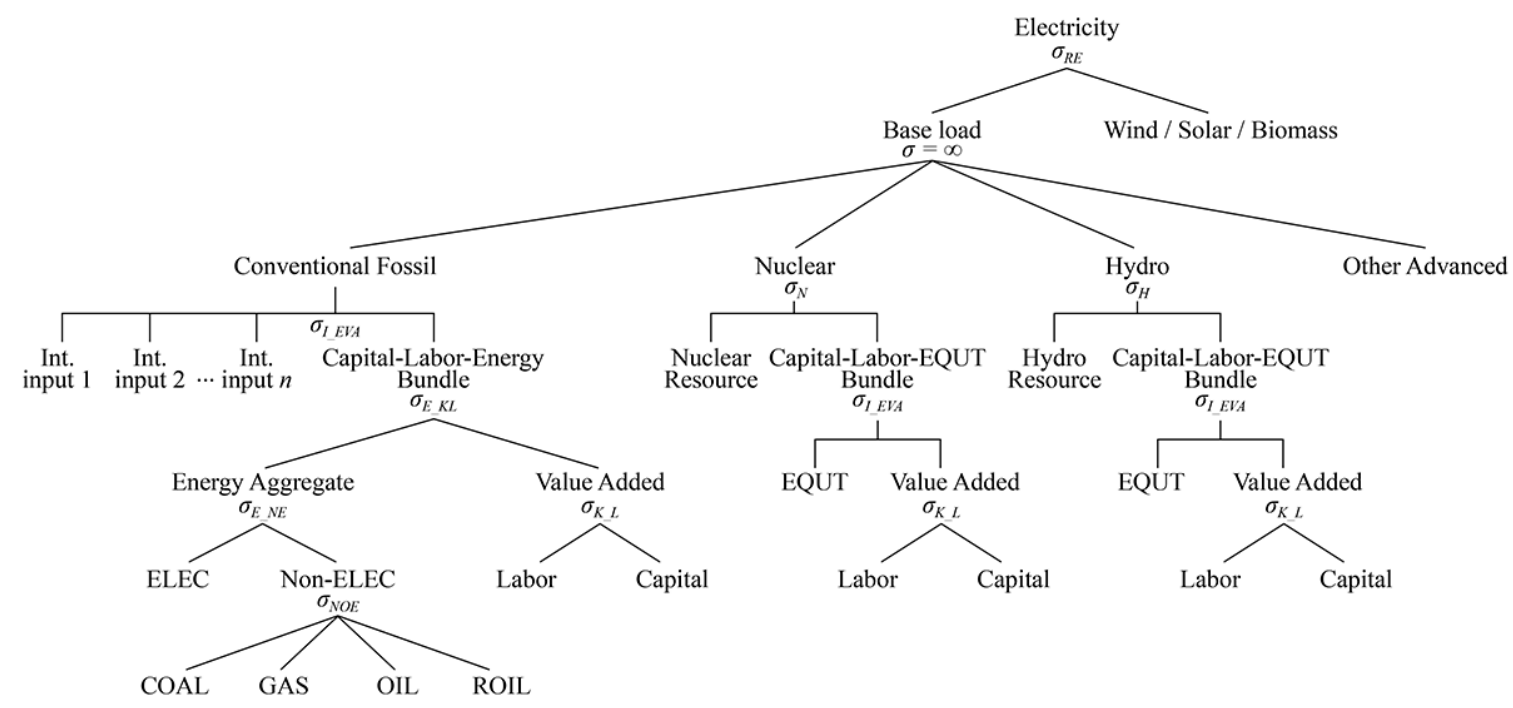

Figure 4. The structure of the electricity sector in the C-GEM.

Table 3. Electricity technologies in the C-GEM.

\begin{tabular}{ll}
\hline Existing & Advanced Technologies \\
Technologies & Wind \\
\hline Coal & Solar \\
Refined oil & Biomass \\
Gas & Advanced nuclear \\
Nuclear & Natural Gas Combined Cycle (NGCC) \\
Hydro & Integrated Gasification Combined Cycle (IGCC) \\
& Natural Gas Combined Cycle with Carbon Capture and Storage (NGCC-CCS) \\
& Integrated Gasification Combined Cycle with CCS (IGCC-CCS) \\
\hline
\end{tabular}

Conventional fossil generation technologies consist of a Leontief combination of non-energy intermediate inputs and an energy-capital-labor bundle. Fossil fuels such as coal, oil and gas enter as imperfect substitutes for each other to avoid one fuel from taking over the market once its relative cost falls below that of its competitors.

As nuclear and hydro are not separately represented in the GTAP database, we use additional information to describe the input-output structure of hydro and nuclear power 
technologies. We parameterize these technologies using information from reports by the International Atomic Energy Agency (IAEA) and the Nuclear Energy Agency of the Organization for Economic Co-operation and Development (OECD/NEA) and the IEA (IAEA, 2008; OECD/NEA, 2010). The structure of the nuclear and hydro CES functions is simplified to focus on fuel resources, capital, labor and equipment as inputs to production.

Advanced generation technologies become available in later years and begin production when their relative cost falls below the levelized cost of incumbent generation types. ${ }^{4}$ With the exception of wind, solar and biomass electricity, we treat advanced electric generation technologies as perfect substitutes for existing technologies as shown in the second level of the production nest. Reflecting the variability of wind, solar and biomass generation, electricity from these sources is treated as an imperfect substitute for other electricity. The structure of advanced technologies is outlined in detail in Section 2.4.

Household consumption in the C-GEM is represented by a single representative consumer in each region, as shown in Figure 5. We use consumption, excluding savings, as a consistent measure for welfare accounting. ${ }^{5}$ Savings enters the currentperiod utility function to proxy for the present value of future consumption. As the savings rate in China is predicted to decline, we set this rate exogenously in C-GEM, as described below.

\footnotetext{
${ }^{4}$ Advanced technologies that operate in the base year (e.g., wind electricity) are included in the inputoutput component of our database. Production structures that specify advanced technologies allow these technologies to expand beyond the level observed in the base year once they become cost competitive.

5 We use consumption measured as equivalent variation in constant 2007 USD as a measure of welfare. We prefer to measure welfare using only consumption rather than income, as including savings in welfare calculations results in double counting of the impact through the savings channel (i.e., under an income measure of welfare, the impact of a change in savings would be counted in the current period and, through changes in investment and ultimately the capital stock, in future periods).
} 


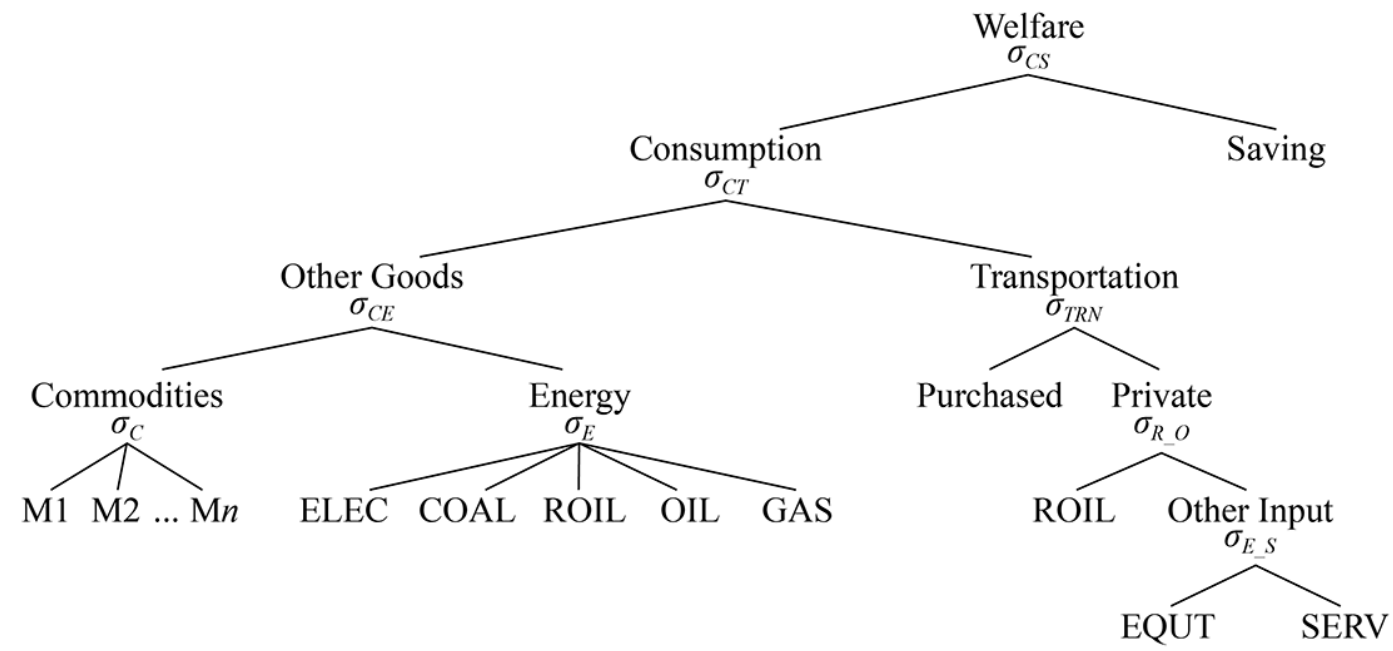

Figure 5. The structure of final demand in the C-GEM.

In the consumption bundle, private transportation is separated from other goods and services, as it accounts for a large share of direct energy use by the household in many regions. Private transportation refers to transportation services supplied to the household through the purchase and operation of passenger vehicles. Inputs to the private transportation sector draw from other industries (e.g., vehicle purchases), services (e.g., maintenance and repairs), and refined oil sectors. Purchased transportation - which is supplied by the transportation industry and includes both short- and long-distance road, air, rail, and marine modes - is included as a substitute for private vehicle transportation. The elasticities employed in the production and utility functions based on estimates from the MIT EPPA model and are reported in Table 4.

Table 4. Elasticities used in the C-GEM model.

\begin{tabular}{|c|c|c|c|}
\hline & Description & Value & Remarks \\
\hline \multicolumn{4}{|c|}{ Production } \\
\hline$\sigma_{\text {Res_OTH }}$ & Resources and other inputs & $0.6-0.7$ & 0.6 for oil and gas, 0.7 for coal \\
\hline$\sigma_{I \_E V A}$ & $\begin{array}{l}\text { Intermediate input and Energy-Capital-Labor } \\
\text { bundle }\end{array}$ & 0 & Applied in all sectors \\
\hline$\sigma_{\mathrm{E} \_\mathrm{KL}}$ & Energy and Value-added bundle & $0.1-0.5$ & $\begin{array}{l}0.1 \text { for electricity, } 0.3 \text { for agriculture, } 0.4 \text { for } \\
\text { energy industry, } 0.5 \text { for other industry }\end{array}$ \\
\hline$\sigma_{\mathrm{E} \_N E}$ & Electricity and Non-electricity input bundle & 0.5 & Applied in all sectors \\
\hline$\sigma_{\mathrm{NOE}}$ & Among non-electricity energy input & $0.1-0.5$ & Different values applied across sectors \\
\hline
\end{tabular}




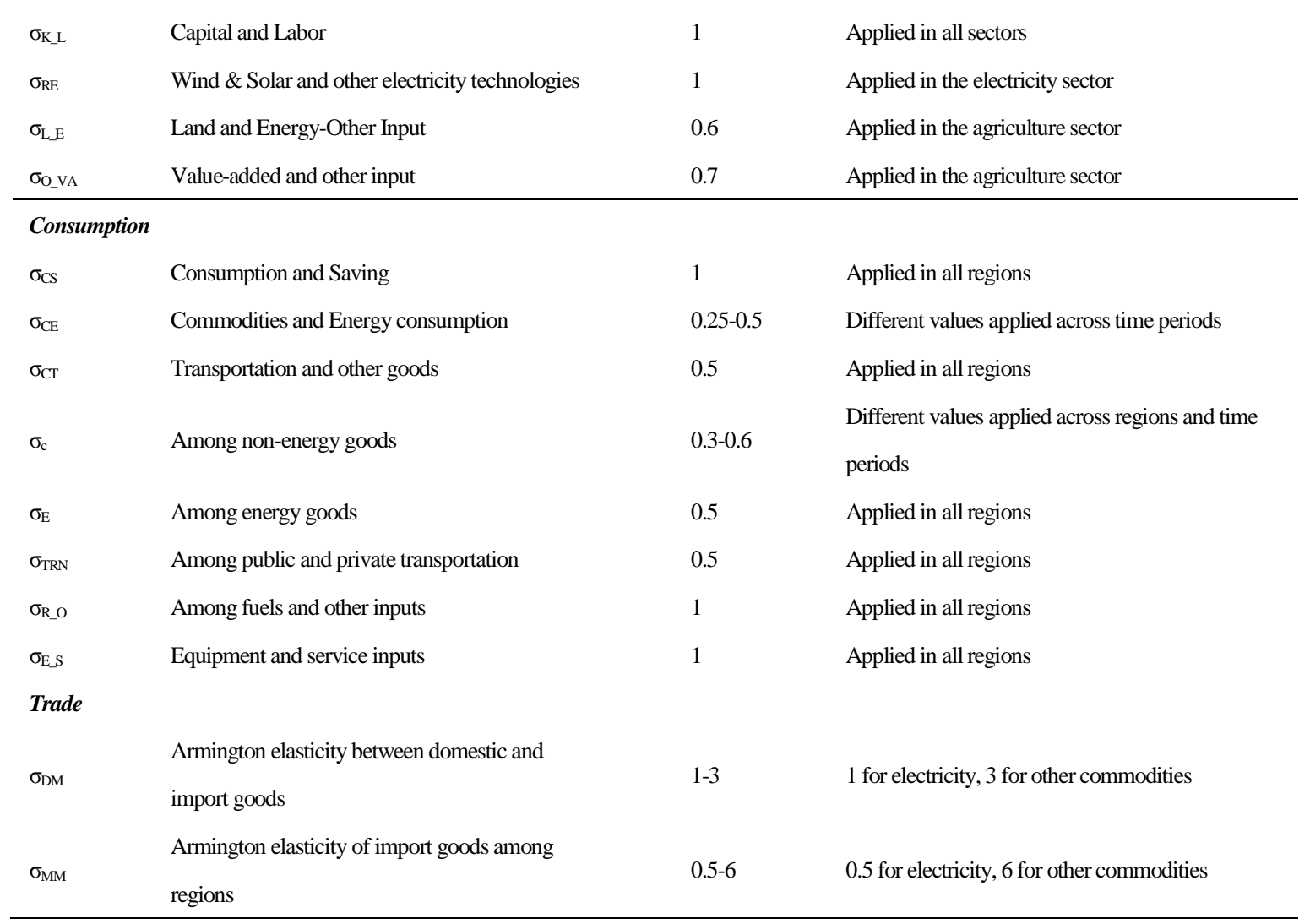

Source: Based on estimates used in the MIT EPPA model (Paltsev et al., 2005).

\section{Emissions}

In the $\mathrm{C}-\mathrm{GEM}, \mathrm{CO}_{2}$ emissions are computed by applying constant emission factors to the fossil fuel energy flows of coal, refined oil and natural gas entering production and final demand. Fuel-specific emissions factors are sourced from IPCC (2006) and are assumed to remain constant across regions and over time. ${ }^{6}$ As $\mathrm{CO}_{2}$ emissions per unit of fuel use are constant in C-GEM, a reduction of emissions in production sectors can only be achieved by reducing fuel use. In the current version of the C-GEM, only fossil-fuel-related $\mathrm{CO}_{2}$ emissions are projected; however, the model framework could be readily extended to account for other non- $\mathrm{CO}_{2}$ greenhouse gases.

\section{International trade, government and investment}

${ }^{6}$ This inventory specifies that tons of $\mathrm{CO}_{2}$ per exajoule (EJ) are 94.6 for coal, 73.3 for oil, and 56.1 for natural gas. 
For all goods except crude oil, international trade in the C-GEM follows the Armington assumption (Armington, 1969). In this approach, domestic production and aggregate imports are modeled as imperfect substitute for each other using a CES function, and aggregate imports are a further CES nest of imports from each region. Elasticity parameters for the Armington specification are sourced from the GTAP database. Crude oil in the C-GEM is modeled as homogeneous good with a single global price, following its treatment in the MIT EPPA model.

The government in the C-GEM is modeled as a passive entity that collects tax revenue on intermediate inputs, outputs, and consumer expenditure and transfers it to the household as a lump-sum payment. Government expenditure is assumed to be part of final consumption and is fully funded by households. Government consumption in the CGEM adopts the same nested CES structure as household consumption, and the government maximizes its utility subject to revenues available.

Investment in the C-GEM is represented by a sector that produces an aggregate investment good using inputs from different sectors which sums to the level of aggregate investment. In each period, investment equals savings and investment becomes available as new capital in the next period.

The C-GEM is formulated and solved as a mixed complementarity problem using the Mathematical Programming Subsystem for General Equilibrium (MPSGE) described by Rutherford (1995) and the Generalized Algebraic Modeling System (GAMS) mathematical modeling language (Rosenthal, 2012) with the PATH solver (Dirkse and Ferris, 1995).

\subsection{The dynamic model}

The static foundation of the C-GEM is used to develop a recursive-dynamic model that allows assessment of energy markets and policy impacts through 2050. By solving the model in each period sequentially and then updating parameter values in the next period to reflect dynamic trends, a recursive-dynamic model assumes that economic 
agents make decisions based on information available in the current period only (Dellink, 2005). The dynamic process of the C-GEM is mainly driven by labor supply growth, capital accumulation, fossil fuel resource depletion, autonomous energy efficiency improvements, and new energy technologies.

\section{Labor supply, capital accumulation and resource depletion}

The effective labor supply in the C-GEM is driven by changes in population and labor productivity in each region over time. The population of each region in the CGEM is specified as an exogenous long-term trend based on estimates from United Nations (2012). In all regions except China, the labor productivity growth rate is estimated by combining population numbers with the historical GDP growth rates and future GDP projections from IMF (2012). For China's labor productivity growth rate, we calibrate the 2010 value at $11 \%$ per year using observed GDP per capita growth rates. Beyond 2010, guided by Chansomphou and Ichihashi (2013), we assume that China's labor productivity growth rate converges at a constant percentage rate to $2.5 \%$ by 2050 . In the Reference scenario, labor productivity is determined endogenously to meet GDP targets. In the Policy scenarios, the same labor-augmenting shifts in production parameters are applied, but the capital stock is endogenous, which means that, to a degree, labor productivity is also endogenous in the Policy scenarios.

The evolution of capital over time in the C-GEM includes both old capital carried over from the previous period and new capital from investment. In all regions except China, we assume a depreciation rate for capital of 5\% per year. In China, we assume that the depreciation rate converges in a linear fashion from $12 \%$ (Bai et al., 2006) to $6 \%$ by 2050 . Additions to the capital stock in each period depend on the share of income allocated to savings in the previous period. For China, following recommendations by OECD (2013), we impose a saving rate which falls from $48 \%$ in 2010 to $43 \%$ in 2020 , $36 \%$ in $2030,30 \%$ in 2040, and then remains constant through 2050. 
All fossil fuel resources in the C-GEM are modeled as scarce resources subject to Hotelling valuation (Hotelling, 1931) in which unit production costs rise as resources are depleted. Fossil resources enter at the top level of the production structure as described in Section 3.2, and trade off with a capital-labor-materials bundle. This substitution reflects the need for more capital and other inputs to recover additional fossil fuel resources as stocks are depleted. In each region and period, available energy resources depend on the initial stock of resources and depletion in the previous period. The substitution elasticity is estimated based on the respective supply curve for each region using the procedure described in Rutherford (1998). Over time, energy resources, $Y$, in sector $E$ and region $R$ are subject to depletion based on annual physical production of fuel $\mathrm{F}$ in the previous period. The residual quantity of the energy resource $Y_{e, r, t}$ available in period $\mathrm{t}$ in region $\mathrm{r}$ can be expressed as:

$$
Y_{e, r, t}=Y_{e, r, t-1}-I \times F_{e, r, t-1}
$$

where $\mathrm{I}$ is the time interval, typically five years in the C-GEM. This specification captures the long-run information of resources prices.

\section{Autonomous energy efficiency improvements}

Observations of historical energy consumption, energy prices, and income growth in industrialized economies have exhibited a trend of energy efficiency improvement, even when energy prices are constant or falling (Schmalensee et al., 1998; Webster et al., 2008). Following the approach commonly used in energy-economic models, we capture these trends using autonomous energy efficiency improvement (AEEI) parameters. In developed regions, guided by Sue Wing and Eckaus (2007), we assume an AEEI growth rate of $1 \%$ per year. Corresponding parameters for developing regions are informed by Cao and Ho (2009) and are $1.7 \%$ per year in China and $1.5 \%$ in other developing regions. The improvements are applied to energy inputs into non-energy sectors. 


\section{New technologies}

The new suite of technologies, which has been referred to as a general class of "Backstop Technology" (William, 1979), is used in the C-GEM to represent energy supply technologies that are not yet commercially available, and may enter the market if and when they become cost-competitive with existing technologies. The cost of each new technology depends on the equilibrium price of all inputs, which is endogenously determined under the CGE framework. The current version of C-GEM includes 11 backstop technologies: three technologies produce perfect substitutes for conventional fossil fuels (crude oil from shale oil, refined oil from biomass, and gas from coal gasification); the remaining eight are electricity generation technologies. Electricity generated from wind, solar and biomass is treated as an imperfect substitute for other sources of electricity, given the intermittency of resource availability. The five remaining technologies, NGCC and NGCC with CCS, IGCC and IGCC with CCS and advanced nuclear, all produce perfect substitutes for conventional electricity output.

The formulation of the model as a mixed complementarity problem (MCP) (Rutherford, 2002b) is an important feature of the model that facilitates the representation of backstop technologies. In an $\mathrm{MCP}$, equilibrium conditions are comprised of a system of weak inequalities and complementary slackness conditions between equilibrium variables and equilibrium conditions (Manne, 1985; Paltsev et al., 2005):

$$
\begin{array}{ll}
A \geq 0, y \geq 0, \quad y(-A)=0 & \text { (The zero profit condition) } \\
x \leq y, p \geq 0, p^{*}(x-y)=0 & \text { (The market clearance condition) } \\
\text { Income }=\text { endowment }+ \text { tax } & \text { (The income balance condition) }
\end{array}
$$

Where $\mathrm{p}$ is a nonzero price vector, $\mathrm{y}$ is nonnegative vector of activity levels, $\mathrm{x}$ is demand, and $\mathrm{A}$ is profits. If profits for a production activity are negative, as is the case for most backstop technologies in the base year, the associated production level is zero. If profits are non-negative, due to a change in economic and/or policy conditions, the associated production activity for a backstop technology will be positive. 
Similar to production for other commodities, advanced technologies are represented by nested CES production functions. A feature of production functions for advanced technologies is that they include a "technology-specific resource input," which enters the top level of the CES functions and represents costs associated with scaling up production. In each period, the penetration of each advanced technology is influenced by the endowment of each technology-specific resource and the elasticity of substitution between the technology-specific resource and other inputs. For each backstop technology, the initial endowment of the technology-specific resource and the elasticity of substitution are assigned to reflect the amount of production that can occur when the technology first operates at the base cost, and the price elasticity of supply. In subsequent periods, the endowment of each technology-specific factor is linked to production of that technology in the previous period, so more production in the previous periods creates the potential for higher penetration rates in subsequent periods. A detailed description of the mechanics and calibration of this approach is provided by Morris et al. (2014).

To specify the production cost of these new technologies, we set input shares for each technology for each region according to the existing information from available sources on the cost of advanced technologies, which include reports on demonstrationscale projects, expert elicitations, and the database of Global Change Assessment Model (GCAM) which reports detailed cost data for novel technologies (Babiker et al., 2001; Paltsev et al., 2005; Electric Power Research Institute, 2011). For China, we rely on the latest available data and views based on expert elicitation of technology costs in China. We use a "markup factor" to capture the cost multiple of the new technologies relative to traditional technologies - markup factors for advanced technologies in China in future model periods are summarized in Table 5. All input shares describing backstop technologies are multiplied by this markup factor. Backstop technologies are assumed to be technically feasible in all model years but the timing of market entry is endogenously determined by their cost competitiveness relative to conventional 
technologies, the costs of which change over time as a result of market supply and demand dynamics (which is in turn a function of fossil resource availability and cost of recovery) as well as policies such as a $\mathrm{CO}_{2}$ price that penalize the cost of fossil fuels in proportion to carbon content.

Table 5. .Relative prices of advanced electric power generation technologies assumed for China (cost of pulverized coal generation is normalized to 1.0 ).

\begin{tabular}{cccccc}
\hline & \multicolumn{5}{c}{ Markup relative to pulverized coal generation $^{1}$} \\
\hline Year & Wind $^{2}$ & Solar PV $^{3}$ & Bioelectricity $^{4}$ & $\begin{array}{c}\text { Natural gas with } \\
\text { carbon capture } \\
\text { and storage }\end{array}$ & $\begin{array}{c}\text { Integrated } \\
\text { gasification } \\
\text { combined cycle }^{6}\end{array}$ \\
$\mathbf{2 0 1 0}$ & 1.3 & 2.5 & 1.8 & 2.35 & 1.55 \\
$\mathbf{2 0 1 5}$ & 1.3 & 2.0 & 1.8 & 2.35 & 1.55 \\
$\mathbf{2 0 2 0}-\mathbf{2 0 5 0}$ & 1.3 & 1.5 & 1.8 & 2.35 & 1.55 \\
\hline
\end{tabular}

${ }^{1}$ Note: The base cost of conventional power generation is assumed to be 0.4 yuan/KWh, the national average cost for producing coal-fired electricity.

${ }^{2}$ Wind power costs are based on expert elicitation and refer to average wind electricity production costs $(0.5-0.55$ yuan/KWh).

${ }^{3}$ Solar PV costs in 2010 (1.0-1.15 yuan/KWh) are based on estimates from NDRC (NDRC, 2011). These costs decrease in 2015 (to 0.8 yuan/KWh) and again in $2020(0.6 \mathrm{yuan} / \mathrm{kWh})$. These reductions are based on the cost reduction targets issued by the Ministry of Industry and Information Technology (MIIT, 2012) .

${ }^{4}$ Biomass power costs $(0.7 \mathrm{yuan} / \mathrm{KWh})$ are based on expert elicitation.

${ }^{5}$ NGCC-CCS costs (0.94 yuan/KWh) are based on literature estimates (Rubin and de Coninck, 2005) and expert elicitation. ${ }^{6}$ IGCC-CCS costs (0.65 yuan/KWh) are based on literature estimates (Rubin and de Coninck, 2005) and expert elicitation.

\section{Scenarios}

To illustrate the capability of the C-GEM for climate and energy policy analysis, we report results from a "Reference" (No Policy) scenario, which does not include any climate policies, and a "Policy" scenario that captures the core mechanisms put forward to reduce $\mathrm{CO}_{2}$ emissions in China. China now is piloting emissions trading systems in seven provinces and cities and has announced plans to establish a national carbon market. This market-based mechanism will be designed to support achievement of $\mathrm{CO}_{2}$ intensity targets by increasing the price of $\mathrm{CO}_{2}$ intensive activities in many industries. The policies include domestic measures-specifically, $\mathrm{CO}_{2}$ intensity (emissions 
divided by GDP) targets - extended through 2050 but at a pace within the range of China's 2020 Copenhagen commitment to decrease its $\mathrm{CO}_{2}$ intensity, and incentives to support low-carbon energy technologies.

Under its Copenhagen commitment, China has pledged to reduce its $\mathrm{CO}_{2}$ intensity by $40 \%-45 \%$ relative to the 2005 level by 2020 . We model this commitment by assuming that China reduces it $\mathrm{CO}_{2}$ intensity by 3.5\% each year from 2010 to 2020 , which results in a reduction in $\mathrm{CO}_{2}$ intensity of $44 \%$ between 2005 and 2020. Beyond 2020, we assume China commits to reduce its $\mathrm{CO}_{2}$ intensity by progressively smaller proportions each year, maintaining a $3 \%$ average annual reduction in $\mathrm{CO}_{2}$ intensity over the period 2020 to 2050 .Under these assumptions, China's $\mathrm{CO}_{2}$ intensity falls by $77.8 \%$ between 2005 and 2050. These intensities are imposed in the model using a cap-andtrade system, where the quantity of emissions permits is set (exogenously) to target emissions intensities and the price of permits is derived endogenously in the model.

Backstop technologies are available in both the Reference and Policy scenarios. Each technology enters if it becomes cost competitive with conventional technologies, either as a result of market dynamics or policy treatment. In this analysis, we use the model to simulate the impact of policies on technology choices.

In addition, we simulate two support mechanisms for low-carbon electricity in the Policy scenario. First, we impose the National Energy Administration's target of 58 gig watts (GW) of nuclear capacity by 2020 and rises to $350 \mathrm{GW}$ by 2050 . These targets are met in the Policy scenario by endogenously adjusting the endowment of the nuclearspecific factor of production, which is consistent with the government granting more licenses for nuclear electricity.

Second, we represent feed-in tariffs ${ }^{7}$ for wind, solar and biomass electricity outlined by China's National Development and Reform Commission in the Policy scenario to

\footnotetext{
7 The feed-in tariff policy is essentially a subsidy to renewable fuel produces that is equal to the difference between the cost of each type of renewable electricity and the price of conventional electricity.
} 
accelerate their expansion. Feed-in tariffs simulated in the Policy scenario are 0.55 CNY per kilowatt hour (kWh) for wind; 0.8 and 0.6 CNY/kWh for solar in, respectively, 2015 and 2020 onward; and $0.75 \mathrm{CNY} / \mathrm{kWh}$ for biomass electricity. These feed-tariffs are imposed in the model using an endogenous subsidy for each generation technology to fix their output prices at the guided level.

For the other regions in the C-GEM, we have applied the same policy assumptions as illustrated in the IEA's new Policy scenario (IEA, 2012). We simulate government policies and measures that were enacted or adopted by mid-2012 as well as any targets for renewable energy, energy efficiency, and national GHG emissions reduction included under the 2010 Cancun Agreements.

\section{Results}

Primary energy in the two scenarios is reported in Figure 6 and emissions results are presented in Table 6. Our discussion of results focuses on the difference between the Reference and Policy scenarios, and the features of C-GEM that influence these changes. First, from Figure 6, we find that without any emission mitigation policies, China's primary energy consumption in the Reference scenario grows rapidly before 2030 and most of the growth is driven by coal use, which increases from 1,632 mtoe in 2010 to 4,515 mtoe in 2050. The Hotelling assumption, which captures how depletion of scarce fossil energy resources affects their costs, increases coal production costs over time and thus helps to slow down the growth rate of coal consumption after 2030, as shown in Figure 6.

Turning to primary energy in the Policy scenario, an increasing $\mathrm{CO}_{2}$ price introduced by an emissions trading system results in large reductions in total energy (to 4,378 mtoe in 2050) and in the use of coal (to 2,027 mtoe in 2050). Wind, solar, biomass electricity and biomass fuel enter in both the Reference scenario and the Policy scenario, but as a result of the renewable subsidy and $\mathrm{CO}_{2}$ price they reach a significantly larger scale under policy. The $\mathrm{CO}_{2}$ price increases the cost of consuming fossil fuel, making the 
backstop technologies (renewables) cost-competitive, which drives a decrease in fossil energy and an increase in energy from backstop technologies (where primary energy from non-combustible sources is calculated using the direct equivalence method (e.g., one million tons of oil equivalent, mtoe, of electricity from wind electricity is considered as one mtoe of primary energy). There is also a decrease in total primary energy consumption in the Policy scenario, relative to the Reference scenario. This decrease is driven by price-induced improvements in energy efficiency, which are controlled by the elasticities of substitution between energy and capital-labor in production functions, and reduced demand for energy-intensive commodities.
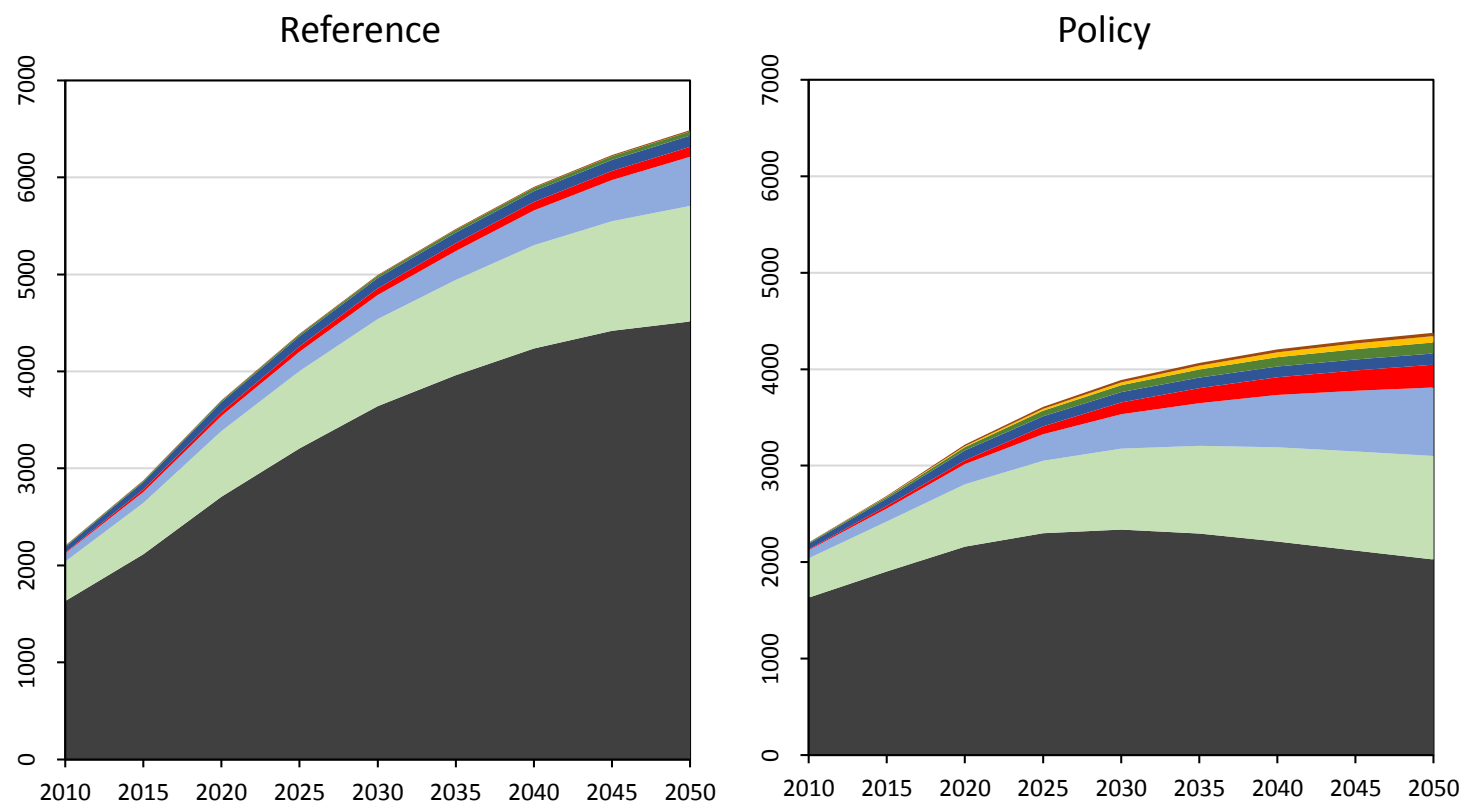

\begin{tabular}{|llll|}
\hline$\square$ Coal & Oil & Natural gas & Nuclear \\
$\square$ Hydro & Wind & Solar & Biomass \\
\hline
\end{tabular}

Figure 6. Primary energy projections for China (mtoe).

Note: Biomass primary energy includes energy from biofuel and biomass electricity.

Table 6 presents emissions in China and the Rest of the World in both scenarios, and the carbon price and welfare changes in the Policy scenario in China. In the Policy 
scenario in 2050, $\mathrm{CO}_{2}$ emissions in China are $42.5 \%$ lower than in the Reference scenario, which are due to changes in the composition of primary energy and reduced energy use, as noted above. The increase in energy prices due to the $\mathrm{CO}_{2}$ price decreases welfare in the Policy scenario by $1.6 \%$ relative to the Reference case. ${ }^{8}$

Table 6. $\mathrm{CO}_{2}$ emissions, $\mathrm{CO}_{2}$ intensity, permit prices and welfare.

\begin{tabular}{|c|c|c|c|c|c|c|c|c|c|}
\hline & 2010 & 2015 & 2020 & 2025 & 2030 & 2035 & 2040 & 2045 & 2050 \\
\hline \multicolumn{10}{|c|}{$\mathrm{CO}_{2}$ emissions - China $(\mathrm{mmt})$} \\
\hline Reference & 7,382 & 9,561 & 12,249 & 14,511 & 16,491 & 18,000 & 19,370 & 20,359 & 21,057 \\
\hline Policy & 7,382 & 8,803 & 10,269 & 11,216 & 11,774 & 12,000 & 12,102 & 12,084 & 12,046 \\
\hline \multicolumn{10}{|c|}{$\mathrm{CO}_{2}$ emissions - Rest of World (mmt) } \\
\hline Reference & 22,118 & 23,538 & 24,963 & 26,946 & 29,132 & 31,323 & 33,361 & 35,421 & 37,350 \\
\hline Policy & 22,118 & 23,565 & 25,020 & 27,042 & 29,269 & 31,502 & 33,586 & 35,684 & 37,651 \\
\hline \multicolumn{10}{|c|}{$\mathrm{CO}_{2}$ intensity - China (mmt per billion USD) } \\
\hline Reference & 1.57 & 1.43 & 1.30 & 1.19 & 1.08 & 0.98 & 0.89 & 0.80 & 0.71 \\
\hline Policy & 1.57 & 1.31 & 1.10 & 0.93 & 0.78 & 0.66 & 0.56 & 0.48 & 0.41 \\
\hline \multicolumn{10}{|c|}{$\mathrm{CO}_{2}$ permit price $(2007 \$ / t)$} \\
\hline Policy & - & $\$ 7.4$ & $\$ 14.1$ & $\$ 19.0$ & $\$ 25.7$ & $\$ 32.9$ & $\$ 41.2$ & $\$ 49.6$ & $\$ 58.4$ \\
\hline \multicolumn{10}{|c|}{ Welfare - China (percentage change in equivalent variation relative to the reference) } \\
\hline Policy & - & $-0.0 \%$ & $-0.6 \%$ & $-0.8 \%$ & $-0.9 \%$ & $-1.2 \%$ & $-1.4 \%$ & $-1.5 \%$ & $-1.6 \%$ \\
\hline
\end{tabular}

As a multi-regional CGE model, C-GEM captures the relationships among inputs, outputs and interactions among regions through trade. Increased energy costs influence economy-wide production through inter-sectoral and other linkages. Table 7 presents proportional changes in sectoral output in the Policy scenario relative to the Reference

\footnotetext{
8 The welfare in C-GEM is evaluated by the total consumption in each country, which includes consumption of both the energy goods and the non-energy goods. The welfare of $u$ is formulated as:

$$
\mathrm{u}\left(p_{e}, p_{n e}\right)=\left(\alpha^{\sigma} p_{e}^{1-\sigma}+(1-\alpha)^{\sigma} p_{n e}^{1-\sigma}\right)^{1 /(\sigma-1)},
$$

where $p_{e}$ and $p_{n e}$ are the prices of energy goods and non-energy goods derived in the model, $\alpha$ is the expenditure share of energy goods, $\sigma$ is the substitution elasticity between energy and non-energy goods consumption. Using this generalized formula and simulated changes in energy and non-energy prices, welfare decreases by $1.3 \%$ in the policy scenario relative to the reference case. This estimate is similar to welfare loss when general equilibrium effects are considered.
} 
case, where results for non-energy sectors are aggregated to the sectoral groups outlined in Table 2 for presentational convenience. As shown in Table 7, emissions-intensive sectors have the largest impact from the $\mathrm{CO}_{2}$ price. The largest output decreases occur for the coal and electricity sectors, and moderate decreases are observed for petroleum products and energy-intensive industries. Natural gas is the only sector for which output increases, due to substitution away from coal and toward gas. Output decreases between $1.3 \%$ and $4.2 \%$ are simulated for other sectors.

Table 7. Changes in output in the Policy scenario relative to the Reference case (\%).

\begin{tabular}{lcccccccc}
\hline Sector & $\mathbf{2 0 1 5}$ & $\mathbf{2 0 2 0}$ & $\mathbf{2 0 2 5}$ & $\mathbf{2 0 3 0}$ & $\mathbf{2 0 3 5}$ & $\mathbf{2 0 4 0}$ & $\mathbf{2 0 4 5}$ & $\mathbf{2 0 5 0}$ \\
\hline Coal & -9.7 & -19.8 & -27.6 & -34.8 & -40.7 & -46.2 & -50.2 & -53.0 \\
Oil & -0.5 & -1.5 & -1.7 & -1.7 & -1.8 & -1.8 & -1.8 & -1.8 \\
Gas & 18.9 & 31.5 & 34.8 & -40.8 & -44.9 & 47.6 & 44.5 & 36.8 \\
Petroleum & -2.1 & -4.4 & -5.7 & -6.5 & -7.3 & -8.1 & -8.9 & -9.8 \\
Electricity & -2.5 & -6.2 & -9.1 & -12.2 & -14.9 & -17.3 & -19.5 & -21.3 \\
Agriculture & 0.1 & -0.5 & -0.8 & -0.9 & -1.0 & -1.1 & -1.2 & -1.3 \\
Energy-int. industries & -1.6 & -3.9 & -4.9 & -5.7 & -6.5 & -7.2 & -7.6 & -7.8 \\
Other production & -0.4 & -1.8 & -2.4 & -2.8 & -3.3 & -3.7 & -4.0 & -4.2 \\
Services & 0.0 & -1.1 & -1.7 & -1.9 & -2.3 & -2.5 & -2.7 & -2.7 \\
\hline
\end{tabular}

The carbon price in China also affects emissions in other regions via its impact on trade flows and fossil fuel prices. Specifically, increases in the price of energy-intensive and other industries in China increase net exports of these commodities in other regions, and reduced demand for fossil fuels in China increase their use elsewhere. Although the C-GEM calculates changes in emissions for 18 regions outside of China, we sum these estimates and report a "Rest of World" aggregate in Table 6. In 2050, Emissions outside of China increase by $300 \mathrm{mmt}$. This results in a leakage rate of $3.3 \% \%^{9}$, which is

9 The low leakage rate is because we are considering leakage from China (instead of leakage to China, as consider by other studies). When climate policies are considered outside of China, this provides an incentive to increase production in China, which is more $\mathrm{CO}_{2}$-intensive than elsewhere. When climate policy is implemented in China, increased production in less $\mathrm{CO}_{2}$-regions will have a lower impact on leakage. Similar leakage rates are calculated by Paroussos et al. (2015). 
defined as the increase in emissions elsewhere divided by the decrease in emissions in China.

\section{Sensitivity analysis}

As results from CGE models can be sensitive to elasticity values, we close by considering separate "high" and "low" cases for the elasticity between energy and labor-capital bundle $\left(\sigma_{E_{-} K L}\right)$ and for the AEEI parameter in China. In the low elasticity case, $\sigma_{E_{-} K L}=0.375$ and in the high case $\sigma_{E_{-} K L}=0.625$ (compared to $\sigma_{E_{-} K L}=0.5$ in the base case used above). $\mathrm{CO}_{2}$ prices and welfare changes in 2050 for the alternative elasticity cases under the Policy scenario are presented in Table 8. By design, results for the base case match those in Table 6. ${ }^{10}$ As $\sigma_{E_{-} K L}$ controls the scope for priceinduced energy efficiency improvements, a lower $\mathrm{CO}_{2}$ price is required to enforce the intensity target in the high case $\left(\$ 50.4 / \mathrm{tCO}_{2}\right)$ than in the low case $\left(\$ 68.3 / \mathrm{tCO}_{2}\right)$. Consequently, welfare is positively related to $\sigma_{E_{-} K L}$. In the AEEI sensitivity case, we consider annual growth rates of $1.4 \%$ and $2 \%$ (compared to $1.7 \%$ in the base cased). In the low AEEI growth case, the emissions price is higher and the welfare cost of the policy nearly twice as large as in the base case. Conversely, a higher AEEI growth rate reduces the carbon price and lowers and the welfare cost. These results show the importance of considering alternative values for key parameter values in climate policy analysis.

Table 8. $\mathrm{CO}_{2}$ prices and welfare change for alternative $\sigma_{E_{-} K L}$ values and AEEI growth rates in the Policy scenario in 2050.

\begin{tabular}{|c|c|c|c|c|c|c|}
\hline & \multicolumn{3}{|c|}{$\sigma_{E \_K L}$} & \multicolumn{3}{|c|}{ AEEI annual growth rate } \\
\hline & 0.375 & 0.5 & 0.625 & $1.4 \%$ & $1.7 \%$ & $2 \%$ \\
\hline $\mathrm{CO}_{2}$ price $(2007 \$ / \mathrm{t})$ & $\$ 68.3$ & $\$ 58.4$ & $\$ 50.4$ & $\$ 79.6$ & $\$ 58.4$ & $\$ 40.4$ \\
\hline Welfare ( $\%$ change) & $-2.1 \%$ & $-1.6 \%$ & $-1.2 \%$ & $-2.7 \%$ & $-1.6 \%$ & $-1.0 \%$ \\
\hline
\end{tabular}

10 We do not report changes in emissions, as $\mathrm{CO}_{2}$-intensity is fixed in the Policy scenario. 
Moreover, to investigate the impact of the Hotelling specifications for fossil energy resources in the C-GEM on modeling outcomes, we double and halve elasticities of substitution between each fuel resource and other inputs in fossil fuel production sectors. The simulation with higher elasticities represents a case where the marginal cost of recovering additional resources rises at a slower rate than in the base case, while lower elasticities are consistent with steeper marginal cost curves. In the Reference scenario, cumulative fossil fuel consumption between 2010 and 2050 is $17 \%$ higher compared to the base case when elasticities are doubled, and $25 \%$ lower when elasticities are reduced by $50 \%$. These results illustrate the importance of carefully selecting and consistently applying appropriate elasticities across scenarios used to analyze the effects of policy, given the high sensitivity of fossil energy demand to the magnitude of the elasticities assumed.

\section{Conclusions}

Due to the size of China's economy and the high $\mathrm{CO}_{2}$ intensity of domestic production, policy decisions in China will have a significant effect on climate change outcomes. We have developed and applied the C-GEM, a global model of economic activity and energy supply, to investigate the impact of climate policy in China over the long term. The model provides a new tool to analyze climate and energy polices in China in a global context.

The paper also illustrated the functionality of the C-GEM by evaluating the future impact of core policies to curtail $\mathrm{CO}_{2}$ emissions based on existing policy commitments in China. These commitments include China's Copenhagen pledge to reduce its $\mathrm{CO}_{2}$ intensity and incentives for introducing low-carbon electricity technologies. Through the study we find that an emissions trading system is indeed an effective instrument for China's emissions mitigation in a long term, as coal consumption is well controlled by the high cost of $\mathrm{CO}_{2}$ emissions. We find that extending similar measures will reduce China's $\mathrm{CO}_{2}$ emissions in 2050 by around $43 \%$ relative to a No Policy baseline. In the 
meantime, the carbon price in China would cause increases in emissions in other regions via its impact on international trade. Due to its size and $\mathrm{CO}_{2}$-intensive fuel mix, a low carbon transition in China will have important implications for global energy markets. The C-GEM is able to capture these effects, and provides a basis for assessing how policy actions in China and elsewhere could contribute to global climate change mitigation in the post-2020 time frame.

\section{References}

Adams, P.D., Parmenter, B.R., 2013. Computable general equilibrium modeling of environmental issues in Australia. Handbook of Computable General Equilibrium Modeling, 1, 553-657.

AlShehabi, O.H., 2013. Modelling energy and labour linkages: A CGE approach with an application to Iran. Economic Modelling, 35, 88-98.

Armington, P.S., 1969. A theory of demand for products distinguished by place of production. IMF Staff Papers, 16, 159-176.

Arrow, K.J., Debreu, G., 1954. Existence of an equilibrium for a competitive economy. Econometrica, 22, 265-290. doi: 10.2307/1907353.

Asafu-Adjaye, J., Wianwiwat, S., 2012. A CGE approach to the analysis of biofuels for promoting energy self sufficiency and security policy in ThailandMethodology. Procedia Engineering, 49, 357-372.

Babiker, M., Criqui, P., Ellerman, A.D., Reilly, J., Viguier, L.L., 2003. Assessing the impact of carbon tax differentiation in the European Union. Environmental Modeling and Assessment, 8, 187-197.

Babiker, M., Reilly, J.M., Mayer, M., Richard, S.E., Ian Sue, W., Hyman, R.C., 2001. The MIT Emissions Prediction and Policy Analysis (EPPA) Model: Revisions, Sensitivities, and Comparisons of Results. MIT Joint Program on the Science and Policy of Global Change, Cambridge, Massachusetts.

Babiker, M., Reilly, J., Viguier, L., 2004. Is international emissions trading always beneficial? Energy Journal, 25, 33-56.

Bai, C., Hsieh, C., Qian, Y., 2006. The return to capital in China: national bureau of economic research. Working Paper 12755. Retrieved from http://www.nber.org/papers/w12755.

Bao, Q., Tang, L., Zhang, Z., Wang, S., 2013. Impacts of border carbon adjustments on China's sectoral emissions: Simulations with a dynamic computable general equilibrium model. China Economic Review, 24, 77-94. 
Böhringer, C., Bye, B., Bye, B., Rosendahl, K.E., 2012. Alternative designs for tariffs on embodied carbon: A global cost-effectiveness analysis. Energy Economics, 34, Supplement 2, S143.

Böhringer, C., Löschel, A., 2006. Computable general equilibrium models for sustainability impact assessment: Status quo and prospects. Ecological Economics, 60, 49-64.

Böhringer, C., Rutherford, T.F., 2013. Transition towards a low carbon economy: A computable general equilibrium analysis for Poland. Energy Policy, 55, 16-26.

Bor, Y.J., Huang, Y., 2010. Energy taxation and the double dividend effect in Taiwan's energy conservation policy - an empirical study using a computable general equilibrium model. Energy Policy, 38, 2086-2100.

Brink, C., Vollebergh, H., Verdonk, M., van der Werf, E., 2014. Quantifying the Effects of Reforming the EU Emissions Trading System-A Computable General Equilibrium Analysis. Fifth World Congress of Environmental and Resource Economists.

Cao, J., Ho, M., 2009. Changes in China's energy intensity: Origins and implications for long-run carbon emissions and climate policies. EEPSEA research reports. Singapore. Retrieved from http://www.eepsea.net/pub/rr/2010-RR12Jing\%20Cao\%20and\%20Mun\%20S\%20HO.pdf.

Capros, P., Van Regemorter, D., Paroussos, L., Fragkiadakis, C., Tsani, S., Charalampidis, I., Revesz, T., 2013. GEM-E3 Model Documentation. Institute for Prospective and Technological Studies, Joint Research Centre.

Cardenete, M.A., Delgado, M.C., 2015. A simulation of impact of withdrawal European funds on Andalusian economy using a dynamic CGE model: 2014-20. Economic Modelling, 45, 83-92.

Chansomphou, V., Ichihashi, M., 2013. Structural change, labor productivity growth, and convergence of BRIC countries. Hiroshima University, Graduate School for International Development and Cooperation (IDEC). Discussion Paper Series, $3(5)$.

China Price Year Book Press., 2009. Price year book of China 2008. Beijing: China Price Year Book Press.

Dellink, R., 2005. Modelling the costs of environmental policy: a dynamic applied general equilibrium assessment. Edward Elgar Publishing.

Dirkse, S. P., Ferris, M.C., 1995. The PATH Solver: a non-monotone stabilization scheme for mixed complementarity problems. Optimization Methods and Software, 5, 123-156.

Electric Power Research Institute., 2011. Program on technology innovation: Integrated generation technology options. Electric Power Research Institute: Palo Alto, California. 
Fujimori, S., Masui, T., Matsuoka, Y., 2014. Development of a global computable general equilibrium model coupled with detailed energy end-use technology. Applied Energy, 128, 296-306.

Hotelling, H., 1931. The economics of exhaustible resources. The Journal of Political Economy, 39, 137-175.

IAEA., 2008. Energy, electricity and nuclear power estimates for the period up to 2030. Vienna: International Atomic Energy Agency.

IEA., 2007. Extended world energy balances [Data set]. IEA World Energy Statistics and Balances. doi: 10.1787/data-00513-en.

IEA., 2012. World energy outlook 2012. OECD/IEA, Paris.

IEA., 2013. $\mathrm{CO}_{2}$ emissions from fuel combustion 2013 [Data set]. IEA $\mathrm{CO}_{2}$ emission statistics.

IMF., 2012. World economic outlook. Washington, DC: International Monetary Fund.

IPCC., 2006. IPCC guidelines for national greenhouse gas inventories. Hayama, Japan: Institute for Global Environmental Strategies (IGES).

Jorgenson, D.W., Yun, K.Y., 2012. Taxation, efficiency, and economic growth. Handbook of Computable General Equilibrium Modeling, 1, 659-742.

Kitwiwattanachai, A., Nelson, D., Reed, G., 2010. Quantitative impacts of alternative East Asia free trade areas: a computable general equilibrium (CGE) assessment. Journal of Policy Modeling, 32, 286-301.

Manne, A.S., 1985. On the formulation and solution of economic equilibrium models. Springer Berlin Heidelberg.

McKibbin, W.J., Wilcoxen, P.J., 2013. A global approach to energy and the environment: The G-cubed model. Handbook of Computable General Equilibrium Modeling, 1, 995-1068.

Melillo, J.M., et al., 2009. Indirect emissions from biofuels: how important? Science, 326, 1397-1399.

MIIT, 2012. the 12th Five-Year-Plan of solar PV industry. The Ministry of Industry and Information Technology, Beijing.

Morris, J.F., Reilly, J.M., Chen, Y.H., 2014. Advanced technologies in energyeconomy models for climate change assessment. MIT JPSPGC Report 272, Retrieved from http://globalchange.mit.edu/files/document/MITJPSPGC_Rpt272.pdf

Narayanan, B., Aguiar A., McDougall, R., 2012. Global trade, assistance, and production: The GTAP 8 data base [Data set]. Center for Global Trade Analysis, Purdue University. Retrieved from http://www.gtap.agecon.purdue.edu/databases/v8/v8_doco.asp.

National Bureau of Statistics of China., 2008. 2007 China energy statistical yearbook. Beijing: China Statistics Press. 
National Bureau of Statistics of China., 2009. 2007 China input-output tables. Beijing: China Statistics Press.

NDRC, 2011. The National Development and Reform Commission (NDRC) announced feed-in tariffs for PV projects, in: Commission, T.N.D.a.R. (Ed.), Beijing.

Nicola, J., 2007. China tops $\mathrm{CO}_{2}$ emissions. Nature, doi:10.1038/news070618-9.

OECD., 2013. Long-term growth scenarios. In Å. Johansson, Y. Guillemette, F. Murtin, D. Turner, G. Nicoletti, C. Maisonneuve, P. Bagnoli, G. Bousquet and F. Spinelli (Eds.), Economic department working papers.

OECD/NEA., 2010. Projected costs of generating electricity. OECD: Paris.

Paltsev, S., et al., 2005. The MIT Emissions Prediction and Policy Analysis (EPPA) model: version 4. MIT JPSPGC Report 125, August, 72 p. Retrieved from http://globalchange.mit.edu/files/document/MITJPSPGC_Rpt125.pdf.

Paroussos, L., Fragkos, P., Capros, P., Fragkiadakis, K., 2015. Assessment of carbon leakage through the industry channel: the EU perspective. Technological Forecasting and Social Change, 90, 204-219.

Qi, T., Winchester, N., Karplus, V.J., Zhang, X., 2014a. Will economic restructuring in China reduce trade-embodied $\mathrm{CO}_{2}$ emissions? Energy Economics, 42, 204-212.

Qi, T., Winchester, N., Zhang, D., Zhang, X., Karplus, V.J., 2014b. The China-inglobal energy model. MIT JPSPGC Report 262, May, 32 p. Retrieved from http://globalchange.mit.edu/files/document/MITJPSPGC_Rpt262.pdf.

Qi, T., Zhang, X., Karplus, V., 2014c. The Energy and $\mathrm{CO}_{2}$ emissions impact of renewable energy development in China. Energy Policy, 68, 60-69.

Rausch, S., Metcalf, G.E., Reilly, J.M., Paltsev, S., 2010. Distributional implications of alternative US greenhouse gas control measures. The BE Journal of Economic Analysis Policy, 10.

Rosenthal, E.R., 2012. GAMS - A user's guide. Washington, DC, USA: GAMS Development Corporation.

Rubin, E., de Coninck, H., 2005. IPCC special report on carbon dioxide capture and storage. Prepared by working group III of the intergovernmental panel on climate change Intergovernmental Panel on Climate Change. Cambridge, UK.

Rutherford, T.F., 1995. Extension of GAMS for complementarity problems arising in applied economic analysis. Journal of Economic Dynamics and Control, 19, 12991324.

Rutherford, T.F., 1998. Economic equilibrium modeling with GAMS. Washington: GAMS Development Corporation.

Rutherford, T.F., 2002a. Lecture notes on constant elasticity functions. Unpublished manuscript. University of Colorado. Retrieved from http://www.gamsworld.eu/mpsge/debreu/ces.pdf. 
Rutherford, T.F., 2002b. Mixed Complementarity Programming with GAMS. Lecture Notes for Econ, 6433.

Rutherford, T.F., 2010. GTAP7inGAMS. Center for Energy Policy and Economics, Department of Management, Technology and Economics, ETH Zurich.

Schmalensee, R., Stoker, T.M., Judson, R.A., 1998. World carbon dioxide emissions: 1950-2050. Review of Economics and Statistics, 80(1), 15-27.

Sue Wing, I., Eckaus, R.S., 2007. The implications of the historical decline in US energy intensity for long-run $\mathrm{CO}_{2}$ emission projections. Energy Policy, 35, 52675286.

United Nations., 2012. World population prospects, the 2012 revision. New York: Population Division, Department of Economic and Social Affairs.

Webster, M.D., Paltsev, S., Parsons, J.E., Reilly, J.M., Jacoby, H.D., 2008. Uncertainty in greenhouse emissions and costs of atmospheric stabilization. MIT JPSPGC Report 165, MIT Joint Program on the Science and Policy of Global Change: Cambridge, MA.

William, D.N., 1979. The efficent use of energy resources. Yale University Press, New Haven.

Zhang, D., Karplus, V.J., Cassisa, C., Zhang, X.L., 2014. Emissions trading in China: progress and prospects. Energy Policy, 75, 9-16. 
Appendix Table 1. Features of CGE models used in recent energy and climate policy studies.

\begin{tabular}{|c|c|c|c|c|c|c|c|c|c|c|c|}
\hline Source & $\begin{array}{l}\text { (Rausch et al., } \\
\text { 2010) }\end{array}$ & $\begin{array}{l}\text { (Böhringer } \\
\text { and } \\
\text { Rutherford, } \\
\text { 2013) }\end{array}$ & $\begin{array}{l}\text { (AlShehabi } \\
\text {,2013) }\end{array}$ & (Brink et al., 2014) & $\begin{array}{l}\text { (Cardenet } \\
e \quad \text { and } \\
\text { Delgado, } \\
2015)\end{array}$ & $\begin{array}{l}\text { (Kitwiwattanachai et } \\
\text { al., 2010) }\end{array}$ & $\begin{array}{l}\text { (Bor and } \\
\text { Huang, } \\
\text { 2010) }\end{array}$ & $\begin{array}{l}\text { (Asafu- } \\
\text { Adjaye and } \\
\text { Wianwiwat } \\
\text {,2012) }\end{array}$ & (Capros et al., 2013) & $\begin{array}{l}\text { (Bao et al., } \\
\text { 2013) }\end{array}$ & $\begin{array}{l}\text { (Fujimori et al., } \\
\text { 2014) }\end{array}$ \\
\hline Base year & 2006 & 2004 & 2001 & 2004 & 2005 & 2001 & 2001 & 2008 & 1984 & 2007 & 2005 \\
\hline Regions & $\begin{array}{l}\text { U.S. domestic } \\
\text { (12 regions) }\end{array}$ & $\begin{array}{l}\text { Global } \\
\text { regions) }\end{array}$ & $\begin{array}{l}\text { Single- } \\
\text { region }\end{array}$ & $\begin{array}{l}\text { Global } \\
\text { regions })\end{array}$ & $\begin{array}{l}\text { Single- } \\
\text { region }\end{array}$ & Global (14 Regions) & $\begin{array}{l}\text { Single- } \\
\text { Region }\end{array}$ & $\begin{array}{l}\text { Single- } \\
\text { Region }\end{array}$ & Global (38 regions) & $\begin{array}{l}\text { Single- } \\
\text { region }\end{array}$ & $\begin{array}{l}\text { Global } \\
\text { regions })\end{array} \quad(17$ \\
\hline $\begin{array}{l}\text { Regional } \\
\text { Coverage }\end{array}$ & $\begin{array}{c}\text { Alaska, } \\
\text { California, } \\
\text { Florida, New } \\
\text { York, New } \\
\text { England, } \\
\text { South East, } \\
\text { North East, } \\
\text { South } \\
\text { Central, } \\
\text { Texas, North } \\
\text { Central, } \\
\text { Mountain, } \\
\text { Pacific }\end{array}$ & $\begin{array}{l}\text { Poland, } \\
\text { Rest of the } \\
\text { EU, } \\
\text { Remaining } \\
\text { industrializ } \\
\text { ed (non- } \\
\text { EU) } \\
\text { regions, } \\
\text { Developin } \\
\text { g countries }\end{array}$ & Iran & $\begin{array}{l}\text { Germany, France, } \\
\text { United Kingdom, } \\
\text { Italy, Netherlands, } \\
\text { Other EU15, } \\
\text { Poland, Rest of } \\
\text { EU27, EFTA } \\
\text { countries, Russia, } \\
\text { United States, } \\
\text { Japan, Australia, } \\
\text { Brazil, Middle } \\
\text { East and North } \\
\text { Africa, China, } \\
\text { India, Other } \\
\text { OECD, Rest of the } \\
\text { World }\end{array}$ & $\begin{array}{c}\text { Andalusi } \\
a\end{array}$ & $\begin{array}{c}\text { China, Japan, } \\
\text { Korea, Indonesia, } \\
\text { Malaysia, } \\
\text { Philippines, } \\
\text { Singapore, } \\
\text { Thailand, Vietnam, } \\
\text { Rest of Southeast } \\
\text { Asia, North America } \\
\text { Free Trade Area, } \\
\text { European Union, } \\
\text { the Australia-New } \\
\text { Zealand Closer } \\
\text { Economic Relations } \\
\text { group, Rest of the } \\
\text { World }\end{array}$ & Taiwan & Thailand & $\begin{array}{l}\text { Austria, Belgium, Bulgaria, } \\
\text { Croatia, Cyprus, Czech } \\
\text { Republic, Germany, } \\
\text { Denmark, Spain, Estonia, } \\
\text { Finland, France, United } \\
\text { Kingdom, Greece, Hungary, } \\
\text { Ireland, Italy, Lithuania, } \\
\text { Luxembourg, Latvia, Malta, } \\
\text { Netherlands, Poland, } \\
\text { Portugal, Slovakia, Slovenia, } \\
\text { Sweden, Romania, USA, } \\
\text { Japan, Canada, Brazil, } \\
\text { China, India, Oceania, } \\
\text { Russian federation, Rest of } \\
\text { Annex I, Rest of the World }\end{array}$ & China & $\begin{array}{c}\text { Japan, China, Ind } \\
\text { ia , Southeast } \\
\text { Asia, Rest of Asia, } \\
\text { Oceania, EU25, } \\
\text { Rest of Europe, } \\
\text { Former Soviet } \\
\text { Union, Turkey, } \\
\text { Canada, United } \\
\text { States, Brazil, } \\
\text { Rest of South } \\
\text { America, Middle } \\
\text { East, North } \\
\text { Africa, Rest of } \\
\text { Africa }\end{array}$ \\
\hline Sectors & 13 & 13 & 22 & 17 & 25 & 14 & 21 & 51 & 31 & 37 & 42 \\
\hline $\begin{array}{c}\text { Static/ } \\
\text { Dynamic }\end{array}$ & $\begin{array}{l}\text { Recursive- } \\
\text { dynamic }\end{array}$ & Static & $\begin{array}{l}\text { Recursive } \\
\text {-Dynamic }\end{array}$ & $\begin{array}{l}\text { Recursive- } \\
\text { Dynamic }\end{array}$ & $\begin{array}{l}\text { Forward } \\
\text {-looking } \\
\text { Dynamic }\end{array}$ & Static & $\begin{array}{l}\text { Recursive- } \\
\text { Dynamic }\end{array}$ & Static & Recursive-Dynamic & $\begin{array}{l}\text { Recursive- } \\
\text { Dynamic }\end{array}$ & $\begin{array}{l}\text { Recursive- } \\
\text { Dynamic }\end{array}$ \\
\hline $\begin{array}{c}\text { Hotelling } \\
\text { specification } \\
\text { for exhaustible } \\
\text { resources }\end{array}$ & Yes & No & No & Yes & No & No & No & No & Yes & No & No \\
\hline $\begin{array}{c}\text { Technology } \\
\text { improvements }\end{array}$ & $\begin{array}{l}\text { Yes, backstop } \\
\text { technologies }\end{array}$ & $\begin{array}{l}\text { Yes, setting } \\
\text { the share } \\
\text { parameters } \\
\text { of future } \\
\text { electricity } \\
\text { technologi } \\
\text { es }\end{array}$ & No & $\begin{array}{l}\text { Yes, backstop } \\
\text { technologies }\end{array}$ & No & No & No & No & $\begin{array}{l}\text { Yes, by production sectors } \\
\text { (Either exogenous or } \\
\text { endogenous). }\end{array}$ & $\begin{array}{l}\text { Yes, by } \\
\text { autonomo } \\
\text { us energy } \\
\text { efficiency } \\
\text { improvem } \\
\text { ent } \\
(A E E I) \text {. }\end{array}$ & $\begin{array}{l}\text { Yes, the share } \\
\text { parameters are } \\
\text { assumed to } \\
\text { change linearly } \\
\text { over time to reach } \\
\text { the projected } \\
2050 \text { values. }\end{array}$ \\
\hline
\end{tabular}

